\title{
Referendum o predčasných vol'bách je protiústavné
}

\author{
Giba, M.*
}

GIBA, M.: Referendum o predčasných vol'bách je protiústavné. Právny obzor, 104, 2021, č. $3,191-207$.

The referendum on early general election is unconstitutional. In this paper, the author deals with a highly topical constitutional law issue - the question of the conformity of the referendum on early general election with the Constitution of the Slovak Republic. The attempt to organize this type of referendum is not new in Slovakia. It has been held twice so far, in 2000 and 2004. Despite serious doubts about its constitutionality, the Constitutional Court has not yet had the opportunity to make a decision on this issue. The author takes a clear position that the referendum on early general election is unconstitutional. He supports this conclusion with arguments of legal theory, written law and case law, taking also some examples and inspiration from comparative constitutional law. According to the author, accepting this kind of referendum as part of the constitutional mechanisms can destabilize the Slovak constitutional system in a serious way. The author claims that the referendum on early election devalues, and therefore violates the importance of the right to vote, it violates the representative mandate, the sovereignty of the people and ultimately, also the principle of democracy and the rule of law.

Key words: referendum, early election, Constitution, democracy, right to vote

Autor sa v článku zaoberá vysoko aktuálnou ústavnoprávnou otázkou - otázkou súladu referenda o predčasných parlamentných vol'bách s Ústavou Slovenskej republiky. Snaha zorganizovat' tento typ referenda nie je v podmienkach Slovenska nová. Doposial' sa konalo dvakrát, ale napriek vážnym pochybnostiam o jeho ústavnosti zatial' Ústavný súd nemal možnost' vyjadrit' k tejto otázke. Autor zaujíma jednoznačný názor, že referendum o predčasných parlamentných vol'bách je protiústavné. Tento záver autor podporuje argumentmi právnej teórie, platného práva a judikatúry. Akceptácia takéhoto druhu referenda ako súčasti ústavných pravidiel hry podl'a autora devalvuje význam aktívneho volebného práva, porušuje reprezentatívny mandát poslancov, suverenity l’udu a v konečnom dôsledku aj princíp demokracie a právneho štátu.

\section{Úvod}

Po dvoch neúspešných a relatívne dávnejších pokusoch z rokov 2000 a 2004 na Slovensku opät' vznikol nápad vyvolat' predčasné parlamentné vol'by prostredníctvom referenda. To, prirodzene, oživilo ústavnoprávne diskusie o súlade takéhoto referenda

* Doc. JUDr. Marián G i b a, PhD., Ústav štátu a práva SAV, Bratislava. 
s Ústavou. ${ }^{1}$ Ešte koncom januára 2021 som pripomenul svoj dlhodobý odmietavý názor k takémuto referendu. ${ }^{2}$ Diskusia nabrala na intenzite, ked' vo februári 2021 môj kolega Vincent Bujňák v denníku Postoj publikoval názor, že takéto referendum odporuje Ústave. ${ }^{3}$ Zniesla sa naňho vlna kritiky v internetových diskusiách - ich úroveň však, žial', často zodpovedá tomu, že sú de facto anonymné a tak ich treba aj brat'. No prišiel útok aj od politických iniciátorov tohto referenda, ${ }^{4}$ ktorý vyvolal ráznu a správnu reakciu Právnickej fakulty Univerzity Komenského v Bratislave. ${ }^{5} \mathrm{~V}$ denníku Postoj medzitým reagoval d'alší môj kolega Tomáš Lalík, ktorý predostrel názor, že referendum o predčasných vol'bách je v súlade s Ústavou. ${ }^{6} \mathrm{~V}$ tom istom období v dennej tlači vyslovil pochybnosti o ústavnosti referenda o predčasných vol'bách Eduard Bárány. ${ }^{7}$

Ked’že spomenutá polemika prebehla v dennej tlači, bola z pohl'adu verejnosti podstatne viditel'nejšia, než keby sa konala na vedeckých fórach. Vyslovit' názor o tom, že referendum o predčasných vol'bách je protiústavné, znamená čelit' kritike, najmä tej laickej, ked’že takýto názor je nepopulárny. Uvedomil som si však, že mnohí z kritikov sú aj vzdelaní a dobromysel'ní l'udia, ktorí zrejme odborné argumenty proti tomuto referendu nepochopili celkom presne. Preto bolo užitočné predostriet' ich komplexne v dennej tlači. Súlad či rozpor referenda o predčasných vol'bách s Ústavou je však v prvom rade dôležitou otázkou ústavnoprávnej teórie a praxe. Z tohto dôvodu, a tiež vzhl'adom na vysokú aktuálnost' tejto otázky, považujem za vhodné zaujat' k otázke postoj aj v rámci vedeckej diskusie.

Ciel'om tohto článku bude priniest' odpoved' na otázku, či referendom možno skrátit' volebné obdobie Národnej rady Slovenskej republiky (d’alej Národná rada), a túto odpoved' podložit' konkrétnymi argumentmi pozitívneho práva, judikatúry a právnej teórie. Najskôr je však nutné, takpovediac, vybrat' pred zátvorku to, čo treba mat' v každej chvíli na zreteli pri čítaní všetkých mojich argumentov.

\section{Nevyhnutné predbežné poznámky}

Ústavné právo upravuje, okrem iného, vzt’ahy medzi najvyššími orgánmi štátu, ktoré sú zároveň orgánmi politickými. Preto má blízko k politike a preto sú mnohé ústavnoprávne problémy súčasne problémami politickými. Je to holý a nevyhnutný fakt. Refe-

\footnotetext{
${ }^{1}$ Argumenty a názory, ktoré autor rozvíja v tomto vedeckom článku, prezentoval 26. 2. $2021 \mathrm{v}$ dennej tlači vo forme novinového komentáru. Dostupné online: Referendum o predčasných vol'bách alebo rozklad suverenity l'udu pod zámienkou jej výkonu. Denník N (dennikn.sk) [cit. 17.3.2021].

${ }^{2}$ Ústavný právnik: Referendum o predčasných vol'bách devalvuje význam volieb i rozhodnutie občanov (podcast). Aktuality.sk [cit. 17. 3. 2021]

${ }^{3}$ Prečo skrátenie volebného obdobia referendom nie je ústavné. Konzervatívny denník (postoj.sk) [cit. 17. 3. 2021].

${ }^{4}$ Fico sa obul do Bujňáka. Dekan fakulty sa ho zastal. SME [cit. 17. 3. 2021].

${ }^{5}$ Vyjadrenie dekana k vyjadreniam doc. Roberta Fica. (uniba.sk) [cit. 17. 3. 2021]. 2021].

${ }^{6}$ Prečo je skrátenie volebného obdobia referendom ústavné. Konzervatívny denník (postoj.sk) [cit. 17. 3. 2021].

${ }^{7}$ Protipandemické opatrenia, ústavné limity a l’udské práva. Slovenské národné noviny (snn.sk) [cit. 17. 3.
} 
rendum o predčasných vol'bách je učebnicovým príkladom takéhoto problému. To, či je toto referendum v súlade alebo v rozpore s Ústavou, je odbornou ústavnoprávnou otázkou. Ale ak sa táto otázka dnes intenzívne rieši, tak preto, lebo ju priniesla ústavná prax v konkrétnom momente a politickom kontexte. Ten je taký, že referendum o predčasných vol'bách je v roku 2021 namierené proti súčasnej vláde a jej parlamentnej väčšine, a o jeho úspech má záujem súčasná opozícia. Na tom nič nemení fakt, že formálne toto referendum vzíde z l'udovej petície, lebo reálne je iniciované politicky.

Ak ústavný právnik chce dat' podl'a svojho najlepšieho vedomia a svedomia odpoved' na akúkol'vek ústavnoprávnu otázku, urobí to takto: predostrie argumenty, ktoré považuje za relevantné, vyvráti možné protiargumenty, svoje úvahy čo najviac rozvinie a potom dospeje k finálnej odpovedi. Klasický postup pri vedeckej práci. Odpoved’ na otázku, či referendum o predčasných vol'bách je v súlade s Ústavou, môže byt' bud' „áno“, alebo „nie“, inej možnosti niet. Tu sa dostávame k spomínanému politickému rozmeru problému: v roku 2021 možnost' „nie“ politicky osoží vládnej koalícii a možnost' „áno“ opozícii. Tým pádom ústavnému právnikovi hrozí, že hoci aj prinesie tie najprepracovanejšie argumenty podl'a svojho najlepšieho vedomia a svedomia, čast' publika ho obviní, že sa snaží pomôct' jednému či druhému politickému táboru. Ten, kto nerozumie (alebo nechce rozumiet') vedeckej diskusii, si neuvedomuje, že ak aj odborná odpoved' na ústavnoprávny problém prináša momentálny osoh pre konkrétny politický tábor, nie je to vôbec zámerom autora. Je to len nevyhnutný dôsledok faktu, že ústavnoprávny problém je zároveň problémom politickým. Čo s tým? Ked' sa rieši taká vážna ústavnoprávna otázka, ako je ústavnost' referenda o predčasných vol'bách, má právna veda mlčat' iba preto, aby jej predstavitelia nečelili obvineniam, že sa nechávajú zat’ahovat' do politiky? Aj to je možnost' a mnohí ju nepochybne využijú. Druhá možnost' je akceptovat' riziko svojho povolania, vstúpit' do diskusie a vnášat' do nej odbornost', vecnost' a nadhl'ad tam, kde politici v mene svojich záujmov neraz bičujú emócie a krivia ústavné právo i fakty.

V roku 2008 som na vedeckej konferencii predniesol a následne publikoval článok k otázke skrátenia volebného obdobia Národnej rady referendom. ${ }^{8} \mathrm{~V}$ ňom som zaujal jednoznačný postoj proti referendu o predčasných vol’bách, ktorý som sa snažil čo najpodrobnejšie odôvodnit'. Zdôrazňujem, že to bolo v roku 2008, v čase, ked' nebolo žiadne referendum o predčasných vol'bách témou a ked' nikto netušil, kto je (bude) Igor Matovič alebo Peter Pellegrini, ani aký bude politický kontext roku 2021. Ani s odstupom trinástich rokov som nič na svojom názore neprehodnotil. Pokial' ide o podstatu veci a hlavné argumenty, $v$ nasledujúcom texte budem významne vychádzat' $\mathrm{z}$ toho, čo som povedal a napísal už v roku 2008. Niektoré tvrdenia a závery budem viac konkretizovat' a miestami reagovat' aj na kolegov.

Posledná vysvetlivka. Nepomýl'me si debatu: ak tvrdím, že referendum o predčasných vol'bách je protiústavné, neobhajujem tým manažérske, komunikačné či politické chyby predstavitel'ov vládnej garnitúry vzídenej z volieb 2020, ani netvrdím, že z nich netreba vyvodzovat' dôsledky. Len neradno je miešat' jablká s hruškami alebo, držiac sa

\footnotetext{
${ }^{8}$ GIBA, M. Referendum o predčasných vol'bách: niekol'ko úvah. In Milniky práva v stredoeurópskom priestore 2008. Bratislava : Právnická fakulta Univerzity Komenského, 2008, s. 572 - 579.
} 
inej metafory, ak debatujeme o koze, debatujme o koze, a ak o voze, tak o voze. Predmetom tejto debaty nie je to, či súčasná vláda zvláda vládnutie a premiér funkciu. Jej predmetom je otázka, či referendum o predčasných vol'bách je ústavne prípustné, alebo nie. A odpoved' musí platit' bez ohl'adu na to, či je rok 2021, či predsedom vlády je Igor Matovič a petíciu za referendum iniciuje Peter Pellegrini, alebo by bol premiérom Peter Pellegrini a petíciu by inicioval Igor Matovič. Na toto netreba zabudnút' ani na sekundu. Základným rozdielom a zároveň spol’ahlivým rozlíšením medzi odborným a politickým názorom je to, či autor na povedanom trvá bez ohl'adu na plynúce volebné obdobia a meniace sa rozloženie síl, alebo svoj „odborný“ názor formuluje a prispôsobuje podl’a toho, čo sa kedy politicky hodí.

\section{Má poslanec právo vykonávat’ svoju funkciu po celé volebné obdobie?}

Už Ernest Valko s Katarínou Babiakovou v roku $2004^{9}$ odmietli referendum o predčasných vol'bách. Ich nosným argumentom, skrátene povedané, bolo, že poslanec má právo vykonávat' svoj mandát v rovnakej dĺžke ako poslanci v iných, neskrátených volebných obdobiach. Skrátit' volebné obdobie je podl'a nich možné bud' len z Ústavou výslovne upravených dôvodov (rozpustenie prezidentom), alebo samotným parlamentom, ak sa uznesie na predčasných vol'bách. ${ }^{10} \mathrm{~K}$ tomu treba, samozrejme, pripočítat' situácie, ked' sa neskracuje celé volebné obdobie, ale mandát zaniká len jednému poslancovi, napríklad z dôvodu odsúdenia v trestnom konaní, ale to nemá nič spoločné s predčasnými vol'bami. ${ }^{11}$ Na túto argumentáciu nadviazal Vincent Bujňák v citovanom komentári pre denník Postoj, ktorý ju rozšíril o európsky rozmer, ked’ poukázal na judikatúru Európskeho súdu pre l’udské práva.

Hoci som presvedčený o protiústavnosti referenda o predčasných vol'bách, myslím si, že argument o práve poslanca na nerušený výkon funkcie je zo všetkých najslabší, z môjho pohl'adu irelevantný. Celkovo síce nesúhlasím s názormi, ktoré v citovanom komentári v denníku Postoj prezentoval Tomáš Lalík, avšak bez problému sa s ním zhodnem na tom, že „l’ud je pán, ktorý rozhoduje, a poslanec je sluha, ktorý slúži“. Inak povedané a mnou často opakované: verejná funkcia v demokracii nie je výsada ani korist', ale služba.

Napriek tomu nemožno prehliadat', že v dnešnom svete je silno prítomná tendencia domáhat' sa všetkého súdnou cestou. Táto čoraz silnejšia judicializácia prenikajúca do všetkých sfér života, v ktorej už aj súdenie sa o verejné funkcie je pomaly pravidlom, so

${ }^{9}$ VALKO, E., BABIAKOVÁ, K. Fenomén predčasných parlamentných volieb a referenda. In Justičná revue, 2004, č. 3, s. $291-298$.

$10 \mathrm{~K}$ otázke skracovania volebného obdobia Národnej rady pozri tiež KAJLA, M. Referendum o predčasných parlamentných vol'bách v podmienkach Slovenskej republiky. In Studia Iuridica Cassoviensia, 2019 , roč. 7, č. 1, s. $21-29$.

${ }^{11}$ Faktom je, že nie všetky dôvody zániku funkcie poslanca Národnej rady sú upravené len v samotnej Ústave. Treba brat' do úvahy aj ústavný zákon č. 357/2004 Z. z. o ochrane verejného záujmu pri výkone funkcií verejných funkcionárov. Pozri BUJŇÁK, V. Ústavná úprava konfliktu záujmov v Slovenskej republike a jej kontaminácia politickými rozhodnutiami. In VEČEŘA, M., HAPLA, M. (eds.): Weyrovy dny právní teorie. Brno : Masarykova univerzita, 2017, s. 75 - 99. 
sebou prirodzene prináša myšlienkový prúd, ktorý má tendenciu nazerat’ na verejnú funkciu viac ako na základné právo jej nositel'a, než ako na službu verejnosti. Podl'a mňa tento koncept ideovo svedčí skôr feudalizmu ako demokracii, preto s ním nesúhlasím. Napriek tomu sledujúc súčasnú realitu uznávam, že debata sa dá posúvat' aj do polohy ochrany „základného práva na nerušený výkon verejnej funkcie“. Takáto optika je dnes možná a je predstavitel'né, že si ju v nejakej miere môžu osvojit' i súdy, ${ }^{12}$ na čo výstižne poukázal aj Vincent Bujňák.

V skutočnosti však otázka ani nestojí tak, či ten, kto zastáva verejnú funkciu, má právo vykonávat' oprávnenia s ňou spojené, kým funkcia trvá - o kladnej odpovedi na túto otázku nie je dôvod pochybovat'. Otázka stojí tak, či sa s verejnou funkciou spája „základné právo“ vykonávat’ ju v plnej dížke predpokladaného funkčného obdobia. Verejných funkcií existuje vel'ké množstvo, ich povaha, náplň a význam pre demokratický právny štát sa rôznia. Na takúto pestrú škálu sa nedá „našit““ jedno paušálne pravidlo. Ak aj pripustím, že pri niektorých verejných funkcionároch by sa dalo uvažovat' o vel'mi zužujúcom výklade možností ich predčasného zbavenia funkcie, funkcia poslanca sotva môže patrit' medzi také. Na túto funkciu sa nepredpisujú žiadne odborné či osobnostné požiadavky, stačí zaradenie na kandidátnu listinu politickej strany a potom iba dôvera meraná počtom hlasov vo vol'bách - nič viac.

Koncept ,práva poslanca na nerušený výkon funkcie v plnej dížke“"vyvracia aj fakt, že predčasné parlamentné vol'by sú vo všeobecnosti prirodzenou (a nevyhnutnou) súčast'ou systému parlamentnej formy vlády, teda takého, kde vláda závisí od dôvery parlamentu. ${ }^{13}$ Naša Ústava výslovne upravuje štyri prípady, v ktorých prezident môže rozpustit' parlament, a jeden prípad, ked' tak dokonca urobit' musí [čl. 102 ods. 1 písm. e)]. ${ }^{14}$ Následkom je vždy zánik mandátu všetkých poslancov a predčasné vol'by. Už len z tohto dôvodu žiadny zvolený poslanec na začiatku volebného obdobia nemôže mat' legitímne očakávanie, že svoj mandát bude vykonávat' celé štyri roky. Nezávisle od jeho vôle a správania môžu nastat' okolnosti, ktoré povedú k predčasným vol'bám - správne na to poukázal aj Tomáš Lalík.

Stojí za pripomenutie, že ani Ústavný súd Českej republiky v slávnej kauze Melčák z roku 2009 nevystaval svoje rozhodnutie ${ }^{15}$ na tom, že by došlo k porušeniu práva poslanca na výkon funkcie v plnej dížke. Ústavný zákon a s ním aj predčasné vol’by zrušil z dôvodu, že Ústava Českej republiky nepoznala skrátenie volebného obdobia Poslaneckej snemovne ústavným zákonom. Z názoru súdu pritom jasne vyplýva, že predčasné ukončenie jej volebného obdobia samo osebe nie je problém - musí však k nemu dôjst' spôsobom, pri ktorom sa rešpektujú ústavne stanovené materiálne i procedurálne pod-

${ }^{12}$ Touto optikou je zretel'ne nasiaknuté napr. aj zjednocujúce stanovisko Ústavného súdu sp. zn. PLz. ÚS 2/2018 z 19. 9. 2018 týkajúce sa odvolávania členov Súdnej rady Slovenskej republiky. Tento judikát je už v súčasnosti prekonaný ústavným zákonom č. 422/2020 Z. z., ktorým sa priamo novelizovala Ústava.

${ }^{13}$ Porovnaj napr. LAUVAUX, P. Le parlementarisme. Paris: Presses universitaires de France, 1997, s. 4.; GIBA, M. a kol. Ústavné právo. Bratislava : Wolters Kluwer, 2019, s. 235 - 236.

${ }^{14}$ Bližšie pozri DOMIN, M. Predčasné parlamentné vol'by. Právna teória a politická prax. In ComenIUS (uniba.sk) [cit. 17. 3. 2021].

${ }^{15}$ Nález sp. zn. Pl. ÚS 27/09 z 10. 9. 2009. 
mienky. Podl'a súdu je to totiž vecou „ochrany oprávnenej dôvery občanov v právo a práva slobodne volit', $t$. j. - okrem iného - práva volit'so znalostou podmienok utvárania $z$ volieb vzídených demokratických orgánov verejnej moci vrátane znalosti ich volebného obdobia“"16. Nie ,právo na nerušený výkon funkcie“, ale práve tento argument, hoci od susedov, zásadne spochybňuje nielen skrátenie volebného obdobia ústavným zákonom, na ktorom by sa dobrovol'ne uzniesla Národná rada, ale aj skrátenie volebného obdobia referendom. Ibaže by sme pripustili, že právo občanov volit' so znalost'ou všetkých podmienok a ochranu ich dôvery v právo možno referendom „,vygumovat““.

\section{Aký je účel predčasných volieb?}

Každý ústavný inštitút má nejaký dôvod existencie a ciel', ktorému má slúžit'. Nie je to inak ani s predčasnými vol'bami. Tak z právnej doktríny, ${ }^{17}$ ako aj platného znenia čl. 102 ods. 1 písm. e) našej Ústavy plynie, že predčasné vol’by sú nástrojom na riešenie politickej krízy, ktorá prerastie do krízy ústavnej. Typický príklad: uprostred volebného obdobia sa rozpadne vládna koalícia, následkom čoho vláda stratí dôveru. Alebo, aj keby formálne dôveru nestratila, stratí parlamentnú väčšinu, a teda schopnost' presadzovat' svoje návrhy v parlamente. V parlamente sa dejú obštrukcie, nevie sa uzniest' na ničom. Vláda reálne nemôže plnit’ svoje funkcie ani program, nanajvýš len živorí zo dňa na deň. Možnosti sú dve: bud’ „pozliepat“" v rámci parlamentu nejakú novú koalíciu tak, že sa čast' tej starej spojí s čast'ou opozície, alebo vykonat' predčasné vol'by. Prvá možnost' býva prakticky nereálna - keby sa dnes rozpadla vládna koalícia, len t’ažko si predstavíme, že by hned' vzápätí zostavili novú vládu napríklad OL'aNO so Smerom-SD a takto by dovládli do riadnych volieb. Predčasné vol'by sú v takom prípade najčistejším a najkorektnejším východiskom z núdze, v ktorej sa objektívne nedá vládnut'. Lenže o takej núdzi sa nedá hovorit' $v$ situácii, ked' má vláda dôveru Národnej rady a aj formálny počet poslancov $\mathrm{v}$ jej radoch dáva $\mathrm{v}$ parlamente väčšinu.

V súlade s logikou parlamentnej formy vlády sú predčasné vždy vol'by východiskom z objektívnej núdze, nikdy však nie nástrojom na revidovanie výsledkov predošlých volieb. ${ }^{18}$ Ak sa inak nedá, treba $\mathrm{k}$ nim pristúpit', ale v ideálnom prípade by nemali byt'.

\section{Ako sa vláde vystavuje účet?}

Zjednodušený pohl'ad na vládnutie u nás je zhruba takýto: l’ud vo vol'bách zvolí parlament, v ňom sa vytvorí väčšina, ktorá zostaví vládu. Vláda predloží parlamentu svoj program, a ked’že má v ňom väčšinu, dostane jeho dôveru. Volebné obdobie parlamentu je štvorročné, preto aj vláda po vol'bách svoj program nastavuje tak, že na ňom bude pracovat' štyri roky, a potom predloží svoj odpočet voličom. Tí jej v parlamentných vol'-

\footnotetext{
${ }^{16}$ Tamže.

${ }^{17}$ Pozri napr. GOHIN, O. Droit constitutionnel. $2^{\mathrm{e}}$ édition. Paris : LexisNexis, 2013, s. 542 a nasl.

${ }^{18}$ GIBA, M. Referendum o predčasných vol'bách: niekol'ko úvah, s. 574.
} 
bách vystavia účet: bud' ju ponechajú pri moci, alebo ju vymenia. Takto to funguje v každej parlamentnej demokracii.

Nejedna vláda sa rok - dva po vol'bách ocitne v situácii, že keby sa v tom momente konali vol'by, dopadla by zle, no v riadnych vol'bách na konci volebného obdobia svoju pozíciu napokon bez problémov obháji. Tiež je bežné, že vláda si po celý čas drží podporu, ktorú v rozhodujúcom momente na konci volebného obdobia stratí. O osude volieb a vlády môžu niekedy rozhodnút' aj externé faktory, ktorých výskyt je z pohl’adu vlády neovplyvnitel'ný, teda náhodný (vojna, hospodárska kríza alebo pandémia). Jedného politika takáto náhoda vynesie na vrchol moci, inému „zlomí väz“. Jeden má št’astie, iný smolu, ktorú vníma ako „nespravodlivost““. Keby sa slovenské vol’by v roku 2020 konali len o týždeň - dva neskôr, teda už v plnej panike z pandémie, ich výsledky by boli zrejme iné už len preto, že účast' by bola bývala určite nižšia. Nikdy sa nedozvieme, aké by boli, komu by to pomohlo a komu uškodilo. Taký je život - nie všetko sa dá predvídat'.

Čo sa však predvídat' dá, je dížka volebného obdobia. To je základný rámec pre každú vládu, podl’a ktorého vie, ako si má rozplánovat' program a nastavit' etapy jeho plnenia. Ak si to sama vláda nepokazí tým, že stratí dôveru parlamentu alebo sa jej v ňom rozpadne väčšina a budú nutné predčasné vol'by, potom vie, že odpočty bude robit' po štyroch rokoch. A zároveň vtedy sa jej bude dat' účet vystavit' najpresnejšie. Ak sa program plánuje na štyri roky a odpočet sa robí po dvoch, nevyhnutne je to skreslené. Ale pozor, tým nechcem povedat', že každá vláda či každý premiér má vládnut’ štyri roky, alebo že majú, nebodaj, „právo na nerušený výkon funkcie v plnej dížke“. Vláda môže a má byt' pri výkone funkcie permanentne „vyrušovaná“, kontrolovaná a konfrontovaná, v prvom rade parlamentom, ktorému sa zodpovedá. Aj od jej vlastnej parlamentnej väčšiny právom očakávame aktivitu, ak je situácia vážna, kritická či neudržatel'ná, a vláda sa nevie či nechce spamätat'. Váhou svojej autority môže pôsobit' i prezident, a potom sú tu d’alšie, viac či menej účinné formy tlaku, ktorý sa dá na vládu či jej člena vyvinút' a môže mat' za následok odchod z funkcie.

Myslím si však, že medzi nástroje tohto tlaku nemá patrit’ referendum o predčasných vol'bách. Myslím si to z dôvodu, ktorý v debate niekedy zaniká, hoci má vel'mi podstatný systémový aspekt. Naratív zberu podpisov pod občiansku petíciu za vyhlásenie referenda o skrátení volebného obdobia v roku 2021 sa nesie viac-menej v polohe, že treba čím skôr skoncovat's Matovičovou vládou. Je možné, že petíciu podporili aj mnohí z tých občanov, ktorí stranu I. Matoviča v roku 2020 volili. Ak sa volič postupne odvráti od toho, komu dal vo vol'bách dôveru, je to jeho právo a v demokracii to nie je nijako nezvyčajný jav.

Ak však uvažujeme o referende o predčasných vol'bách ako o sankčnom nástroji voči aktuálnej vláde, tak pozor, aby sa nestalo, že pre strom prehliadneme les. Ak dnes pripustíme, že referendum o predčasných vol'bách je v súlade s Ústavou, bude to znamenat', že môže byt' použité kedykol'vek v budúcnosti. Žiadna budúca vláda si nebude môct' byt' istá, že hoci si udrží parlamentnú väčšinu, bude mat’ na realizáciu svojho programu štyri roky. K čomu to povedie? Vel’mi pravdepodobne k tomu, že každá vláda uvažujúca prak- 
ticky sa bude od začiatku a po celý čas vládnutia správat' tak, ako keby bola vo volebnej kampani. Už dost' dlho je miera populizmu dennodenne prítomného v politike neznesitel'ná. Skúsenost' pritom dokazuje, že táto miera stúpa priamo úmerne tomu, ako sa blížia vol'by ${ }^{19}$, a jej vyvrcholenie môže byt' vskutku ,impozantné“ (spomeňme si na poslednú schôdzu parlamentu pred vol'bami 2020). Čo potom nastane, ked' prestane platit' štvorročné volebné obdobie Národnej rady? Teda, presnejšie povedané, ked' sa zo štvorročného obdobia stane de facto iba subsidiárne pravidlo, ktoré bude platit’ len pre prípad, že sa referendom nerozhodne o predčasných vol'bách?

\section{Ako funguje suverenita l'udu?}

Princíp suverenity l’udu na Slovensku vyplýva z čl. 2 ods. 1 Ústavy: „Štátna moc pochádza od občanov, ktorí ju vykonávajú prostredníctvom svojich volených zástupcov alebo priamo“. Pre zástancov referenda o predčasných vol'bách je toto hlavný tromf: l’ud môže konat' aj priamo, nielen prostredníctvom parlamentu, l'ud je viac ako parlament, ergo l'ud môže rozhodnút' aj o tom, že ukončí volebné obdobie aktuálneho parlamentu a zvolí si nový. Na prvý pohl'ad jednoduché a lákavé, v skutočnosti vel'mi zložité. Ústava nie je iba jeden článok bez kontextu. Je to sústava hodnôt a princípov vyjadrených tou či onou formou vo všetkých jej ustanoveniach. Na každé ustanovenie sa treba pozerat' ako na jednu zo súčiastok vel'kého súkolia, ktoré môže dobre fungovat' len ako celok. Inými slovami, ide o systematický prístup k Ústave, ktorý implikuje, že všetky jej ustanovenia sa musia vykladat' a uplatňovat' vo vzájomných súvislostiach ako jeden celok, ktorý sa spravuje určitými spoločnými zásadami a stojí na určitých hodnotách. ${ }^{20}$

Ani princíp suverenity l'udu sa nedá izolovat' od zvyšku Ústavy, absolutizovat' a vnímat' tak, že l'ud môže v referende rozhodnút' kedykol'vek o čomkol'vek. Stojí za pripomenutie, že francúzska ústavná teória i prax už dávno riešila podobnú otázku, t. j. či referendum podlieha ústavným obmedzeniam, alebo ho nemožno príliš ,,Zväzovat““ ústavnými limitmi, ked’že ide o výkon suverenity l'udu. Málokto dnes vo Francúzsku pochybuje, že platí prvá možnost'. Jeden z najvýznamnejších francúzskych konštitucionalistov 20. storočia Georges Vedel k tomu výstižne poznamenal, že suverenita l'udu ,nemôže vo vzt'ahu k ústave požívat'žiadnu nadradenost "a je ,len jednou normou ústavnej sily popri iných“21. Inými slovami, zaradenie suverenity l’udu medzi základné ustanovenia Ústavy „vyjadruje princíp, ktorý sa uplatňuje len v rámci určenom ostatnými článkami ústa$v y^{\text {“22. }}$. A do tretice, ,suverénna moc nie je taká, ktorá nepodlieha žiadnym pravidlám, ale taká, ktorej nemožno určovat' pravidlá bez jej súhlasu“"23. Na týchto názoroch nie je nič

\footnotetext{
${ }^{19} \mathrm{Na}$ túto skutočnost' lakonicky poukázal aj Ústavný súd v odôvodnení nálezu sp. zn. PL. ÚS 27/2015 z 25. 11. 2015 .

${ }^{20}$ Porovnaj CIBULKA, L'. a kol. Štátoveda. Bratislava : Wolters Kluwer, 2017, s. 124. Pozri tiež nález Ústavného súdu sp. zn. PL. ÚS 12/01 zo 7. 12. 2007.

${ }^{21}$ VEDEL, G. Souveraineté et supraconstitutionnalité. In Pouvoirs, č. 67, 1993, s. 79 - 97.

${ }^{22}$ CHANTEBOUT, B. Droit constitutionnel. 26édition, Paris : Dalloz, 2009, s. 462.

${ }^{23}$ RIALS, S. Les incertitudes de la notion de Constitution sous la Ve République. In Revue du droit public et de la science politique en France et à l'étranger, 1984, s. 587 - 606.
} 
šokujúce - naopak, sú prejavom súdnosti a rešpektu k logike, na ktorej stoja moderné ústavy. Aj slovenská doktrína sa vyjadruje v rovnakom duchu: „Referendum predstavuje výkon moci suveréna, avšak zároveň je suverén obmedzovaný ústavou, ktorú sám prijal (por. preambulu $k$ ústave). Výkon moci občanov v referende tak nie je ekvivalentnýs pôvodnou ústavodarnou mocou, ktorá je a priori neobmedzená. "24

Článok 93 ods. 3 Ústavy výslovne zakazuje konat' referendum o niektorých veciach. ${ }^{25}$ Článok 95 ods. 2 a čl. 125b ods. 1 zároveň umožňujú kontrolovat’ súlad predmetu referenda s Ústavou. S ohl'adom na systematický výklad Ústavy, ale predovšetkým na znenie čl. $125 \mathrm{~b}$ ods. 1 in fine ${ }^{26}$ treba zdôraznit', že súlad predmetu referenda možno skúmat' nielen vo vzt'ahu ku čl. 93 ods. 3, ale vo vzt'ahu ku ktorémukol'vek ustanoveniu Ústavy alebo ktorémukol'vek ustanoveniu ktoréhokol'vek ústavného zákona.

Keby sme pripustili, že suverenita l'udu v referende je nadradená zvyšku Ústavy preto, lebo ide o konanie samotného suveréna, stala by sa Ústava zbytočnou a v referende by sa dalo odhlasovat' prakticky všetko s argumentom, že l’ud je suverénny. Nielen skrátenie volebného obdobia parlamentu, ale napríklad aj jeho predĺženie. Prečo nie? Ved' ked' je l'ud so svojimi sluhami taký spokojný, že si praje zachovat' parlament presne v tomto zložení, prečo by mu rovno nepredížil volebné obdobie? Rovnako by sa mohlo predčasne ukončit' funkčné obdobie prezidenta republiky, na základe referenda z občianskej iniciatívy, kde by na platnost' stačila účast' nadpolovičnej väčšiny oprávnených voličov. Teda tak, že by sa úplne obišli mechanizmy l'udového hlasovania o odvolaní prezidenta so všetkými podmienkami a dôsledkami, ktoré upravuje čl. 106 Ústavy. Tiež by sa mohlo skrátit' funkčné obdobie všetkým sudcom Ústavného súdu s argumentom, nech parlament a prezident vyberú lepších. A ak nevyberú, tak otázkou d’alšieho referenda by mohlo byt' zrušenie Ústavného súdu. Absurdné? Áno, ale presne k tomuto by viedla absolutizácia jedného ústavného princípu - suverenity l'udu - na úkor zvyšku Ústavy. A ešte by sa mohlo tvrdit', že je to ,demokratické“.

Článok 2 ods. 1 Ústavy hovorí, že l'ud vykonáva svoju moc bud' prostredníctvom svojich zástupcov, alebo priamo. Bud' - alebo. Sú to dva významovo rovnocenné, ale technicky rozdielne spôsoby výkonu moci, z ktorých každý má svoje pravidlá. Paradoxom referenda o predčasných vol'bách je, že ono v podstate zmiešava tieto dva rozdielne spôsoby výkonu moci do jedného bizarného celku. V tomto referende sa totiž neprijíma žiadne konkrétne vecné rozhodnutie s dlhodobou platnost'ou. Takým by bolo napríklad referendum o otázkach: Prajete si vystúpenie z Európskej únie? Ste za priamu vol'bu prezidenta? Ste za zavedenie dvojkomorového parlamentu? Ste za to, aby Ústavný súd mohol posudzovat' ústavnost' ústavných zákonov? O týchto otázkach si môžeme mysliet' čokol'vek, ale prinajmenšom dávajú zmysel v tom, že majú nejaký reálny meritórny obsah, na ktorý môžu mat' občania taký alebo opačný názor a hl'adá sa, ktorý je väčšinový.

${ }^{24}$ LALÍK, M., LALÍK, T. Zákon o Ústavnom súde Slovenskej republiky. Komentár. Bratislava : Wolters Kluwer, 2019, s. 340.

${ }_{25}^{2}$ „Predmetom referenda nemôžu byt’ základné práva a slobody, dane, odvody a štátny rozpočet.“

${ }^{26}$ „Ústavný súd rozhoduje o tom, či predmet referenda, ktoré sa má vyhlásit' na základe petície občanov alebo uznesenia Národnej rady Slovenskej republiky podl'a čl. 95 ods. 1, je v súlade s ústavou alebo s ústavným zákonom." 
A sú to všetko otázky, pri ktorých štát môže fungovat' aj s možnost'ou áno aj s možnost'ou nie a musí sa uznat', že dat' ich na rozhodnutie občanom ako zdroju moci je legitímne a demokratické.

No referendum o predčasných vol'bách žiadnu meritórnu otázku trvalo nerieši. Nezavádza žiadne pravidlo ani žiadne neruší, nemení žiadne z rozhodnutí aktuálneho parlamentu ani mu nebráni až do prípadných predčasných volieb vykonávat' všetky svoje kompetencie. Hovorí len, že namiesto jedných zástupcov, ktorí prijímajú rozhodnutia v mene l'udu, chce l'ud iných, ktorí ich opät' budú prijímat' v jeho mene. L'ud teda tak či tak nebude mat' priamy dosah na prijímané rozhodnutia, len vymení zástupcov. Nevie, akí budú, ani či budú lepší, ale vymenia sa. Aktom priamej demokracie sa dožadujeme aktu zastupitel'skej demokracie. Prijímame rozhodnutie, že chceme prijat' rozhodnutie vo vol'bách. Priama a zastupitel'ská demokracia v jednom.

Podstatou referenda však je, že l'ud prijíma konkrétne rozhodnutie namiesto svojich zástupcov. Bud’ vo veci, ktorá je príliš vážna na to, aby sa mohla rozhodnút' „iba“ na úrovni zástupcov (obligatórne referendum - v našom prípade vstup do štátneho zväzku s iným štátom). Alebo vo veci, o ktorej by síce mohli rozhodnút' aj zástupcovia, ale v konkrétnej situácii sa $\mathrm{z}$ nejakého dôvodu vec predloží na rozhodnutie priamo l'udu (fakultatívne referendum). Ako uvádza doktrína: „Zo systematického výkladu ústavy vyplýva, že prostredníctvom referenda občania realizujú zákonodarnú moc. Referendom sú občania oprávneni prijímat rozhodnutia nezávisle od orgánov verejnej moci. “27

Referendum o predčasných vol'bách nezapadá do týchto schém. Vo svojej podstate - aj ked' sa to tak nenazve - vlastne ide o odvolanie poslancov z funkcií. Odvolanie z funkcie je, vo všeobecnej rovine, vec, ktorá je v demokracii možná. Akurát sa nepraktizuje voči poslancom parlamentu nikde, kde funguje reprezentatívny mandát. Odvolanie poslanca je možné vtedy, ak sa mandát koncipuje ako imperatívny - poslanec tu nie je zástupcom celého l’udu, ale len svojich voličov (svojho obvodu), ktorých príkazy by mal plnit' a ktorí ho môžu odvolat', ak nie sú s jeho prácou spokojní ${ }^{28}$ Takéto niečo umožňovala (aj ked' skôr len teoreticky) napríklad Ústava Československej socialistickej republiky z roku $1960 .^{29}$

Zastupitel'ská demokracia odmieta imperatívny mandát. Je postavená na myšlienkovej konštrukcii, že každý poslanec zastupuje všetkých občanov, teda celý l'ud. Zastupuje aj tých, ktorí volit' neprišli alebo volili strany, ktoré sa nedostali do parlamentu. Nie je viazaný príkazmi v žiadnom jednotlivom prípade a účty je povinný skladat' v d'alších vol'bách, ak sa uchádza o znovuzvolenie. Nejednému laikovi sa to nemusí páčit', no vysvetl'ovat' teraz všetky súvislosti nie je možné. ${ }^{30}$ Avšak už len to, že to takto funguje v celom demokratickom svete po niekol'kých storočiach skúseností s demokraciou, jasne nasvedčuje, že sú na to dobré dôvody. Referendum o predčasných vol'bách fakticky zna-

\footnotetext{
${ }^{27}$ LALÍK, M., LALÍK, T. Zákon o Ústavnom súde Slovenskej republiky. Komentár, s. 340.

${ }^{28}$ Pozri DOMIN, M. Volebné právo a volebné systémy. Bratislava : Wolters Kluwer, 2017, s. 17 - 18.

${ }^{29}$ Pozri tiež OROSZ, L. a kol. Volebné právo. Košice : Právnická fakulta UPJŠ, 2015, s. 191 - 195.

${ }^{30}$ Podrobne pozri napr. DOMIN, M. Volebné právo a volebné systémy, s. $14-43$.
} 
mená hromadné odvolanie všetkých poslancov, čo je v rozpore s reprezentatívnym mandátom aj celou filozofiou našej demokracie. ${ }^{31}$

Tomáš Lalík v obhajobe tohto referenda v denníku Postoj prirovnal vzt’ah medzi voličmi a poslancami ku vzt’ahu medzi klientom a advokátom, ktorý ho zastupuje v súdnom spore. Súhlasím s ním, že by bolo absurdné, keby klient nemohol advokátovi zrušit' plnú moc a zvolit' si iného advokáta a bolo by nepredstavitel'né tvrdit', že advokát má právo klienta zastupovat' počas celého súdneho procesu. To všetko je pravda. Problém je, že vzt'ah klienta s advokátom sa povahou a fungovaním vôbec nepodobá vzt’ahu medzi l'udom a poslancami v modernej demokracii. Advokát zastupuje individuálne záujmy konkrétneho klienta v spore, kde na druhej strane stojí iný jednotlivec so svojím advokátom, ktorý zase zastupuje jeho záujmy. Ten istý advokát by nemohol zastupovat' oboch, lebo by bol v konflikte záujmov. Poslanec však nemá za úlohu zastupovat' záujmy jedného občana proti záujmom iného občana. Zastupuje celý l'ud, o ktorého blaho sa má usilovat' najlepšie, ako vie. L'ud tvoria všetci občania, konkrétni jednotlivci z mäsa a kostí. Ústavnoprávne je však l'ud jeden abstraktný subjekt, ktorý nemožno stretnút', rozprávat' sa s ním ani sa ho dotknút'. L’ud sa vyjadruje bud' vo vol'bách, ked' si zvolí svojich zástupcov, aby mu po určitý vopred známy a obmedzený čas slúžili najlepšie, ako vedia, alebo v referende, ked' rozhodne o otázke v konkrétnej veci namiesto svojich zástupcov.

Najzávažnejší argument, pre ktorý považujem referendum o predčasných vol'bách za protiústavné, je, že toto referendum devalvuje význam aktívneho volebného práva, teda práva volit'. Práva, ktorého prostredníctvom sa realizuje suverenita l'udu. Každý volič, súčast' abstraktného suverénneho l’udu, má svoj volebný hlas, pomyselný „dielik“ moci rozhodnút', ako bude vyzerat' zastupitel'ský zbor. Aj ked” sa ten dielik môže pri niekol'kých miliónoch voličov javit' ako kvapka v mori, nik iný nemá väčší, teda všetky hlasy sú si rovné. Moc rozhodnút' vo vol'bách však nespočíva len v možnosti určit' zloženie zastupitel'ského zboru, ale aj v možnosti urobit' tak s platnost'ou na určitý čas. Váha rozhodnutia nie je tá istá, ked' sa robí na štyri roky a ked'sa robí na rok. Prípadne, ked' sa nevie, na ako dlho sa robí, lebo každú chvíl'u môžu byt' referendom vyvolané predčasné vol'by. Ak voliči pri vol'bách nebudú vediet', ako dlho ich rozhodnutie bude platit', môžu časom stratit' záujem o vol'by. Nedá sa pochybovat' o tom, že akt, ktorý sa potenciálne deje každú chvíl'u, je menej významný ako akt, ktorý sa deje len raz za štyri - pät' rokov.

Akceptovanie referenda o predčasných vol'bách ako súčasti pravidiel hry vnesie permanentnú neistotu do procesu volieb a dlhodobo zníži ich reálny význam. Zdevalvuje to

\footnotetext{
${ }^{31}$ Po uverejnení môjho komentára v Denníku N ma Vincent Bujňák upozornil na jedno rozhodnutie Ústavného súdu Mad'arska, o ktorom som nemal vedomost'. Ide o rozhodnutie č. 2/1993. (I. 22.) AB vo veci č. 1651/G/1992 zo dňa 19. 1. 1993. Ústavný súd v ňom odmieta skrátenie volebného obdobia parlamentu referendom a okrem iného uvádza: „Referendum k rozpusteniu Národného zhromaždenia, ktorého výsledok Národné zhromaždenie zaväzuje, vedie $k$ zániku poslaneckých mandátov, a slúži $k$ vyvodeniu zodpovednosti členov parlamentu a samotného parlamentu smerom $k$ voličom. Referendum by v skutočnosti znamenalo odvolanie parlamentu voličmi." http://public.mkab.hu/dev/dontesek.nsf/0/75E5E98AB4A78405C1257ADA0052B3B9?OpenDocument [cit. 17. 3. 2021].
} 
zastupitel'skú demokraciu, avšak bez toho, aby ju aspoň nahradilo priamou - ako už bolo povedané, $v$ referende o predčasných vol'bách sa neprijíma žiadne vecné rozhodnutie, je to len rozhodnutie o tom, že sa znova zvolia zástupcovia.

\section{Z judikatúry Ústavného súdu SR}

Ústavný súd sa vo svojej rozhodovacej činnosti za bezmála tri desat'ročia účinnosti Ústavy venoval referendu opakovane a hojne, no k ústavnosti referenda o predčasných parlamentných vol'bách sa zatial' nemal možnost' vyjadrit' meritórne a neurobil to ani obiter dictum. Komplexný rozbor judikatúry Ústavného súdu v oblasti referenda ${ }^{32}$ by presahoval kapacitný rámec tohto článku. Postačí preto pripomenút' jeho podstatný záver formulovaný v roku 2014, podl'a ktorého ,sa prostredníctvom čl. 93 ods. 3 ústavy kladie zábrana referendám s takými otázkami, ktorých úspech by znamenal narušenie konceptu základných práv a slobôd v podobe znižovania ich štandardu vyplývajúceho z medzinárodnoprávnej úpravy i úpravy vo vnútroštátnom právnom systéme, a to v miere ohrozujúcej charakter právneho štátu. (...) Pri zniženi štandardu určitého základného práva a slobody prostrednictvom referenda sa od ústavného súdu žiada byt' ostražitým z dôvodu už konštatovaného potenciálneho nebezpečenstva narušenia podstaty a zmyslu základného práva a slobody, a to vo vztahu ku všetkým adresátom jeho pôsobenia alebo $v$ relácii $k$ druhovo určenej skupine právnych subjektov. $V$ takýchto pripadoch by bolo povinnostou ústavného súdu poskytnút' dôslednú ochranu základným právam a slobodám aj v zmysle ústavných princípov formujúcich ich kvalitatívnu stránku. " ${ }^{33} \mathrm{Z}$ dôvodov, ktoré som uviedol v závere bodu 5 tohto článku, sa domnievam, že referendum o predčasných vol'bách napíňa znaky zníženia štandardu aktívneho volebného práva (čl. 30 ods. 1 prvá veta Ústavy) spôsobom, ktorý presne zodpovedá spôsobu, ktorý v citovanej pasáži rozhodnutia z roku 2014 Ústavný súd vylúčil.

$\mathrm{V}$ tomto kontexte stojí za zmienku ešte jedno rozhodnutie Ústavného súdu z roku $2013,{ }^{34}$ ktoré je svojím spôsobom kuriózne. Išlo o individuálnu ústavnú st’ažnost' občana Slovenskej republiky, ktorá smerovala proti postupom, ktorými boli vyvolané predčasné parlamentné vol'by 2012. St’ažnost' teda mierila predovšetkým proti ústavnému zákonu č. 330/2011 Z. z. o skrátení volebného obdobia Národnej rady. Ústavný súd túto st’ažnost' odmietol prijat' na d'alšie konanie, meritórne rozhodnutie teda nevzniklo. Okrem toho išlo, z povahy veci, o rozhodovanie v senáte, nie v pléne. Ako problém bolo nastolené skrátenie volebného obdobia parlamentu ústavným zákonom, nie referendom. Toto rozhodnutie bolo vydané ešte pred rozhodnutím PL. ÚS 24/2014, kde plénum podalo zásadný výklad čl. 93 ods. 3 Ústavy, pokial' ide o základné práva ako predmet referenda. Zo všetkých týchto dôvodov treba preto hned' skraja poznamenat', že na účely prípadného posudzovania ústavnosti referenda o predčasných vol’bách Ústavným súdom nemá toto rozhodnutie žiadnu zásadnejšiu relevanciu (vo význame predchádzajúcej rozhodovacej

\footnotetext{
${ }^{32}$ Pre bližší prehl'ad jej najpodstatnejších zložiek pozri napr. GIBA, M. a kol. Ústavné právo, s. 207 - 226.

${ }^{33}$ Nález Ústavného súdu sp. zn. PL. ÚS 24/2014 z 28. 10. 2014.

${ }^{34}$ Uznesenie Ústavného súdu sp. zn. II. ÚS 153/2013 z 28. februára 2013.
} 
činnosti, ktorá by mohla pôsobit’ precedenčnou váhou). Bližší rozbor si však zaslúži vzhl'adom na bohatý okruh argumentov obsiahnutých v odôvodnení.

V tomto konaní sa st'ažovatel', takpovediac, pokúsil o slovenskú obdobu českej kauzy Melčák s tým rozdielom, že nevystupoval ako poslanec parlamentu, ktorého práva sa mali porušit' skrátením volebného obdobia, ale ako občan - volič, ktorému malo byt' zasiahnuté do aktívneho volebného práva skrátením volebného obdobia parlamentu, na ktorého vol'be sa podiel'al. St’ažovatel', študent práva, rozvinul akademicky celkom hodnotnú argumentáciu, výrazne inšpirovanú práve českým rozhodnutím Pl. ÚS 27/09. Hoci Ústavný súd st’ažnost' odmietol prijat' na d'alšie konanie, v odôvodnení rozvinul akademicky tiež vel'mi hodnotné úvahy, v ktorých nechýbajú argumenty právnej doktríny či komparatívny prehl'ad rozhodovacej činnosti zahraničných ústavných súdov. Ústavný súd odôvodnenie zakončil výslovnou poznámkou o svojom presvedčení, ,že st'ažnost' prispeje k ústavnoprávnemu diskurzu, čo bolo zaiste jedným z cielov stažovatel'a“, čím vel'mi otvorene a pravdivo pomenoval hlavný význam, ktorý toto rozhodnutie má.

Senát Ústavného súdu v odôvodnení odmietol názor, že by skrátením volebného obdobia parlamentu mohlo dôjst' k zásahu do aktívneho volebného práva občanov, a to s argumentom, že občan nie je nositel'om subjektívneho práva na Ústavou stanovenú dížku volebného obdobia parlamentu. Inšpiroval sa názorom Jana Filipa, ${ }^{35}$ na ktorý aj explicitne odkázal. S argumentom ako takým možno súhlasit' - napokon, potvrdzuje ho už len samotná existencia mechanizmu rozpustenia parlamentu. Stále sa však možno pýtat', či neexistencia subjektívneho práva občana na stanovenú dížku volebného obdobia parlamentu znamená, že jeho skrátením sa nedá v určitých prípadoch nedovolene zasiahnut' do aktívneho volebného práva občanov. Argumenty o devalvácii tohto základného práva, ktoré som uviedol, sú totiž závažné a zrejme len t’ažko by sa obhajovalo tvrdenie, že rozhodnutie robené na štyri roky a rozhodnutie robené na jeden rok majú rovnakú váhu. Ústavný súd tvrdí, že právo občana na slobodnú vol'bu svojich zástupcov (čl. 30 ods. 1 prvá veta Ústavy) sa samotnými vol'bami vyčerpáva. Toto je však vel'mi zužujúce videnie zastupitel'skej demokracie. Ak sa senát pozeral na vec iba cez prizmu individuálneho subjektívneho práva, ktoré by mohlo byt' porušené, zrejme je jeho záver logický - naozaj sa nedá tvrdit', že občan má právo na štvorročné obdobie parlamentu, nemá ho o nič viac ako poslanec.

No dalo by sa dôjst' aj k inému záveru. Nesmelo by sa však na problém nazerat' len optikou hl'adania konkrétnej ujmy, ktorá mohla vzniknút' jednému individuálne špecifikovanému občanovi. Na vec treba nazerat' systematicky a aktívne volebné právo vidiet' v spojení so základnými ustanoveniami Ústavy, predovšetkým s princípom demokracie a suverenity l'udu. Práve cez aktívne volebné právo sa tieto princípy realizujú a, takpovediac, „ožívajú“. Treba sa pozerat' na vec nie cez pohl'ad jedného občana, ale l'udu. Zároveň je však pravda, čo naznačil aj samotný senát, že konanie o ústavnej st’ažnosti nie je na takúto optiku tou najlepšou procedúrou.

Aj napriek tomuto senátnemu rozhodnutiu zastávam názor, že ak sa otázka ústavnosti referenda o predčasných vol'bách dostane pred plénum Ústavného súdu, ten bez

\footnotetext{
${ }^{35}$ FILIP, J. Zkrácení volebního období. In Parlamentní zpravodaj, 1997 - 1998, č. 12, s. 132 - 134.
} 
problému bude môct' zohl'adnit' aj tieto systémové prvky a nebude musiet' hl'adat' len hmatatel'nú ujmu na individuálnych právach konkrétneho jednotlivca na to, aby dospel $\mathrm{k}$ tomu, že takéto referendum znižuje štandard aktívneho volebného práva.

\section{Záver}

Referendum o predčasných vol'bách neporušuje ,právo poslanca na nerušený výkon funkcie v plnej dížke“. Takéto právo nejestvuje a - logicky - čoho niet, to nemožno porušit'. Predsa však významne odporuje našej Ústave. Aby som bol konkrétny, odporuje jej článku 1 odseku 1, pokial' ide o princíp demokratického štátu aj pokial' ide o princíp právneho štátu. Odporuje tiež článku 2 odseku 1, podl'a ktorého štátna moc patrí občanom a tí ju vykonávajú jednou z dvoch dostupných možností, no nie oboma naraz. Ďalej odporuje článku 30 odseku 1 prvej vete, podl'a ktorej ,občania majú právo podiel'at'sa na správe verejných vecí priamo alebo slobodnou vol'bou svojich zástupcov", a to v spojení s čl. 1 ods. 1 a čl. 2 ods. 1 . Súčast'ou tohto práva, ak má mat' reálny obsah a vážnost', totiž musí byt' nielen možnost' občana odovzdat' vo vol'bách hlas, ale aj možnost' urobit' to s platnost’ou na určitý čas. V spojení s článkom 73 odsekom 1 je tento čas pri Národnej rade štyri roky. Pretože by sa takýmto referendom znížil existujúci štandard aktívneho volebného práva, odporuje aj článku 93 odseku 3. Odporuje, v neposlednom rade, i článku 73 odseku 2, lebo takéto referendum je nezlučitel'né s konceptom reprezentatívneho mandátu. Odporuje, napokon, celkovej filozofii našej Ústavy a našej demokracie. A keby aj rovno, per impossibile, neodporovalo ničomu z toho, tak stále vel'mi spol'ahlivo odporuje zdravému rozumu.

Nie je pravda, že dve minulé referendá o predčasných vol'bách boli ústavné a nik ich nespochybňoval, práve naopak. Pravdou len je, že v roku 2000 ešte neexistovala možnost' prezidenta dat' posúdit' ústavnost' predmetu referenda Ústavnému súdu ${ }^{36}$ a v roku 2004 ju prezident nevyužil. Treba verit', že tentoraz hlava štátu nepremárni túto príležitost'. Ak svoje oprávnenie využije, nebude to znamenat', že sa stavia za súčasnú koalíciu alebo proti súčasnej opozícii. Bude to len prejav jej zmyslu pre povinnost' zachovávat' i obhajovat' Ústavu (čl. 104 ods. 1) a svojím rozhodovaním zabezpečovat' riadny chod ústavných orgánov (čl. 101 ods. 1).

Ak sa táto referendová otázka dostane pred Ústavný súd, už toto bude výhra bez ohl'adu na výsledok. Dozvieme sa záväznú odpoved' na 20-ročný ústavnoprávny spor. Ak Ústavný súd povie, že referendum o predčasných vol'bách je protiústavné, bude to znamenat', že nielen toto, ale ani žiadne d'alšie referendum tohto typu sa nebude môct' konat'. A keby náhodou Ústavný súd dospel k rozhodnutiu, že referendum o predčasných vol'bách je ústavné, tiež je lepšie to vediet', ako žit' v neistote. Fakticky by tým zanikol reprezentatívny mandát poslanca Národnej rady a slovenský ústavný systém by sa zásadne zmenil. Zo súčasnej polopriamej demokracie (teda systému, kde sa zastupitel'ská demokracia alternatívne kombinuje s možnost'ou l'udu rozhodovat' o niektorých veciach priamo, namiesto svojich zástupcov), by sme sa posunuli do systému, ktorý by nebol ani polopriamou ani zastupitel'skou ani priamou demokraciou a pre ktorý súčasná štátoveda

\footnotetext{
${ }^{36}$ Táto možnost' bola zavedená ústavným zákonom č. 90/2001 Z. Z.
} 
zrejme nemá presné pomenovanie. Netvrdím, že preto Slovensko zahynie. Ale obávam sa, že sa tým zvalia základy, na ktorých súčasná republika stojí.

\section{Doslov}

Zamýšl'am sa ešte nad jednou vecou. Pri nej už nejde o súlad referenda o predčasných vol'bách s Ústavou, ale je vel'mi podstatná z hl'adiska kvality fungovania demokracie a demokratických mechanizmov: politická zodpovednost'. Hoci je tento pojem na Slovensku stále skôr niečím ako cudzie slovo a tomu zodpovedá aj dlhodobá úroveň jej (ne)vyvodzovania, politická zodpovednost' by mala byt' kl'účový a samozrejmý prvok každej fungujúcej demokracie.

Celoštátne referendum je vždy vel'mi vážna vec. Ak sa ním majú dosiahnut' predčasné parlamentné vol'by, jeho vážnost' sa tým ešte násobí. Každé referendum má, prirodzene, nejakého iniciátora, ktorý sa snaží dosiahnut' ním určitý ciel'. Aj ked' vzíde referendum formálne z občianskej iniciatívy, za touto iniciatívou je vždy niekto, bez koho by nemohla byt' úspešná, lebo zozbierat' 350-tisíc podpisov nedokáže žiadna skupina občanov len tak, bez toho, aby bola vybavená organizačnou štruktúrou, materiálnymi a personálnymi možnost'ami. Za iniciatívou súčasného referenda o predčasných vol'bách sú opozičné politické strany, ktoré s touto myšlienkou prišli a ktoré poskytujú svoje personálne i materiálne zázemie na to, aby sa podarilo vyzbierat' dostatok podpisov za jeho vyhlásenie. Presne tak, ako ho rovnakému referendu poskytli v rokoch 2000 a 2004. Toto všetko je v poriadku - iba to konštatujem.

Ak referendum prebehne a bude úspešné, malo by znamenat' predčasné vol'by ${ }^{37}$ a vyvodenie politickej zodpovednosti voči súčasnej vláde a parlamentnej väčšine. Moja otázka znie: aká politická zodpovednost’ bude vyvodená, ak referendum úspešné nebude? V rokoch 2000 a 2004 nebola vyvodená žiadna a politickí iniciátori referenda to vopred deklarovali. Ak to bude tak i teraz, opät' tu bude tá istá nerovnováha. Opozícia de facto žiada od vlády, aby sa predčasne podrobila súdu voličov, a využíva na to nástroj priamej demokracie. No ak bude postoj voličov taký, že predčasné vol'by nechcú (čo bude pravda i vtedy, ak bude referendum neplatné pre nízku účast'), tak politickým posolstvom referenda bude, že voliči podržali vládu. Ak potom iniciátori referenda nevyvodia voči sebe žiadnu politickú zodpovednost', bude to znamenat', že len volajú na zodpovednost' vládu bez toho, aby ju sami boli ochotní niest' a čokol'vek riskovat'.

Kým bol vo Francúzsku pri moci bývalý prezident Charles de Gaulle (1958 - 1969), referendum používal často. ${ }^{38}$ Bola to jednak vec jeho presvedčenia, istá forma osobného

\footnotetext{
${ }^{37}$ Osobitnou otázkou, ktorú teraz neriešim, je, aké konkrétne kroky by v prípade úspechu referenda o predčasných vol'bách mali nasledovat', aby k tým vol’bám skutočne došlo. Postup prostredníctvom prijatia ad hoc ústavného zákona o skrátení volebného obdobia je dnes značne spochybňovaný a preto riskantný. Je preto možné (a implicitne to vyplýva aj zo spôsobu, akým je tentokrát sformulovaná referendová otázka), že iniciátori referenda, resp. ich právni poradcovia si to v kontexte rozhodnutia Ústavného súdu PL. ÚS 24/2014 predstavujú tak, že po úspešnom referende jednoducho predseda Národnej rady vyhlási nové vol’by, pričom sa neoprie o Ústavu, ale o výsledky referenda publikované v Zbierke zákonov.

${ }^{38}$ Podrobne pozri napr. GOHIN, O. Droit constitutionnel, s. 578-636; GIBA, M. Súdna kontrola ústavnosti vo Francúzsku. Bratislava : Wolters Kluwer, 2017, s. 111 - 138.
} 
dialógu s Francúzmi, ale niekol'kokrát ho vyslovene použil ako „bič“" na parlament, ktorý sa staval proti jeho návrhom. Každé referendum, ktoré sa za jeho éry konalo, sa konalo fakticky, hoci nie formálne, vždy z jeho iniciatívy. Dvakrát sa to stalo spôsobom, že referendum bolo procedurálne výrazne na hrane Ústavy, a de Gaulle to vedel. ${ }^{39}$ Pred každým jedným referendom však verejne deklaroval, že ak neprejdú jeho referendové návrhy, odstúpi z funkcie prezidenta republiky. Presne to sa aj v roku 1969 stalo: de Gaulle odstúpil na druhý deň po referende, ktoré preňho dopadlo neúspešne. Nebola to žiadna hanba, naopak, bol to prejav osobnostnej integrity prezidenta a jeho rešpektu voči l'udu. A tiež uvedomenia si vážnosti, akú referendum v demokracii má.

Keby politickí iniciátori slovenských referend o predčasných vol'bách vkladali do hry svoju politickú zodpovednost', nič by to nezmenilo na mojom názore o protiústavnosti takého referenda. Musel by som však uznat' prinajmenšom dve veci. Po prvé, že je to férový postoj, ktorý sa nevyhýba zodpovednosti, ale, naopak, je prejavom pripravenosti niest' ju. A teda že iniciácia referenda je prejavom politickej odvahy. Po druhé, že referendum je prejavom úcty k občanom, lebo ich názor bude rešpektovaný za každých okolností, a nielen vtedy, ked' povedia to, čo politickí iniciátori referenda chcú počut'. Referendum by malo relevantné dôsledky bez ohl'adu na to, ako by dopadlo: bud' právne aj politické v radoch koalície, ak budú predčasné vol'by, alebo len politické v radoch opozície, ak predčasné vol'by nebudú. Jeden aj druhý prípad by mohol slovenskú politickú scénu niekam posunút', a preto by referendum mohlo mat' zmysel aspoň politicky. No bez tohto rozmeru, ak bude referendum neúspešné, jeho jediným ,prínosom“ bude únava a pachut’ z kampane, ktorá mu bude predchádzat'.

Na úplný záver ešte jeden postreh z Francúzska. Známy tret'orepublikový socialista Léon Gambetta počas kampane pred parlamentnými vol'bami v roku $1877^{40}$ predniesol v Lille prejav, z ktorého vošla jedna veta do dejín. Povedal ju na margo prípadnej neochoty svojich protivníkov akceptovat' výsledky volieb a ich možnej snahy vyvolávat' predčasné vol'by dovtedy, kým im neprinesú priaznivý výsledok. Podl'a historických záznamov po tejto vete zazneli dve salvy mohutného potlesku publika a pokriky: „Nech žije republika!“" Gambetta povedal: „Quand la France aura fait entendre sa voix souveraine, croyez-le bien Messieurs, il faudra se soumettre ou se démettre." V slovenskom preklade sa síce stráca trochu z pôvodnej zvučnosti, no pointa zostáva: „Ked’ Francúzsko prehovorí svojím suverénnym hlasom, veru páni, bude treba sa podriadit'alebo sa porúčat'،

\section{Literatúra}

BUJŇÁK, V. Prečo skrátenie volebného obdobia referendom nie je ústavné. In Konzervatívny denník (postoj.sk) [cit. 17. 3. 2021]

${ }^{39}$ Podrobne pozri GIBA, M. Súdna kontrola ústavnosti vo Francúzsku, s. 123 - 137.

${ }^{40}$ Tieto vol'by boli predčasné a nasledovali po udalostiach, pre ktoré sa v ústavných dejinách Francúzska ustálil názov „,kriza 16. mája 1877“. Podrobne pozri napr. CHEVALLIER, J.-J. Histoire des institutions et des régimes politiques de la France de 1789 à 1958. 9e édition, Paris : Armand Colin, 2001, s. 310 - 324. 
BUJŇÁK, V. Ústavná úprava konfliktu záujmov v Slovenskej republike a jej kontaminácia politickými rozhodnutiami. In VEČEŘA, M., HAPLA, M. (eds.) Weyrovy dny právni teorie. Brno : Masarykova univerzita, 2017, s. $75-99$.

CHANTEBOUT, B. Droit constitutionnel. 26e édition, Paris : Dalloz, 2009.

CHEVALLIER, J.-J. Histoire des institutions et des régimes politiques de la France de 1789 à $1958.9^{\mathrm{e}}$ édition, Paris : Armand Colin, 2001

CIBULKA, L. a kol. Štátoveda. Bratislava : Wolters Kluwer, 2017

DOMIN, M. Volebné právo a volebné systémy. Bratislava : Wolters Kluwer, 2017

DOMIN, M. Predčasné parlamentné vol'by. Právna teória a politická prax. In ComenIUS (uniba.sk) [cit. 17. 3. 2021]

FILIP, J. Zkrácení volebního období. In Parlamentní zpravodaj, 1997 - 1998, č. 12, s. 132 - 134.

GIBA, M. Referendum o predčasných vol'bách: niekol'ko úvah. In Mil'niky práva v stredoeurópskom priestore 2008. Bratislava : Právnická fakulta Univerzity Komenského, 2008, s. $572-579$

GIBA, M. Referendum o predčasných vol'bách alebo rozklad suverenity l'udu pod zámienkou jej výkonu. Denník N (dennikn.sk) [cit. 17. 3. 2021]

GIBA, M. Súdna kontrola ústavnosti vo Francúzsku. Bratislava : Wolters Kluwer, 2017

GIBA, M. a kol. Ústavné právo. Bratislava : Wolters Kluwer, 2019

GOHIN, O. Droit constitutionnel. $2^{\mathrm{e}}$ édition. Paris : LexisNexis, 2013

KAJLA, M. Referendum o predčasných parlamentných vol'bách v podmienkach Slovenskej republiky. In Studia Iuridica Cassoviensia, 2019, roč. 7, č. 1, s. $21-29$

LAUVAUX, P. Le parlementarisme. Paris : Presses universitaires de France, 1997

L'ALÍK, M., L'ALÍK, T. Zákon o Ústavnom súde Slovenskej republiky. Komentár. Bratislava : Wolters Kluwer, 2019

L'ALÍK, T. Prečo je skrátenie volebného obdobia referendom ústavné. In Konzervativny denník (postoj.sk) [cit. 17. 3. 2021]

OROSZ, L. a kol. Volebné právo. Košice : Právnická fakulta UPJŠ, 2015

RIALS, S. Les incertitudes de la notion de Constitution sous la Ve République. In Revue du droit public et de la science politique en France et à l'étranger, 1984, s. $587-606$

VALKO, E., BABIAKOVÁ, K. Fenomén predčasných parlamentných volieb a referenda. In Justičná revue 2004, č. 3, s. $291-298$

VEDEL, G. Souveraineté et supraconstitutionnalité. In Pouvoirs, č. 67, 1993, s. $79-97$ 